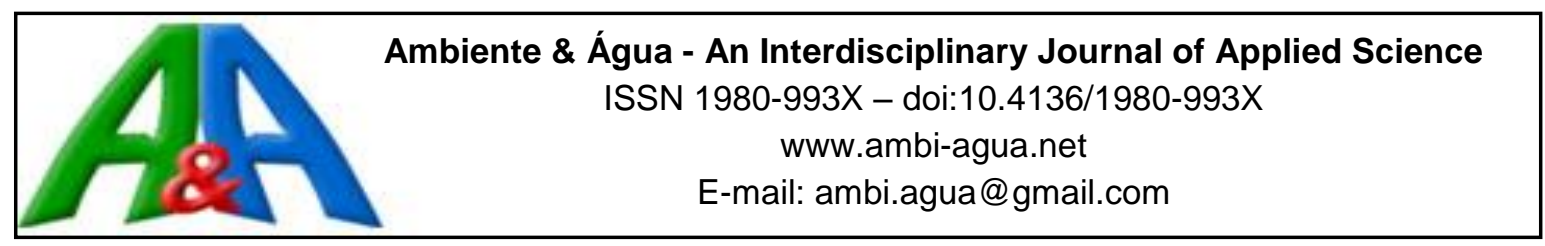

\title{
Insalubrious touristic environments and schistosomiasis transmission in Pernambuco, Brazil
}

\author{
ARTICLES doi:10.4136/ambi-agua.2151
}

Received: 21 Jun. 2017; Accepted: 07 Feb. 2018

\author{
Constança Simões Barbosa' ${ }^{1}$; Elainne Christine de Souza Gomes ${ }^{1}$; \\ Rodrigo Moraes Loyo ${ }^{1 *}$; Mariana Izabel Sena Barreto de Melo Cavalcanti ${ }^{1}$; \\ Iris Edná Pereira Silva ${ }^{1}$; Andréa Sobral de Almeida ${ }^{2}$; Reinaldo Souza-Santos ${ }^{2}$ \\ ${ }^{1}$ Fundação Oswaldo Cruz (FIOCRUZ), Recife, PE, Brasil \\ Instituto Aggeu Magalhães (IAM). Departamento de Parasitologia \\ E-mail: constanca.barbosa@gmail.com, elainnechristine1@gmail.com, \\ rodrigoloyo@live.com, marianasenabarreto@gmail.com, yris_silva@live.com \\ ${ }^{2}$ Escola Nacional de Saúde Pública Sergio Arouca (ENSP), Manguinhos, RJ, Brasil \\ Departamento de Endemias Samuel Pessoa (DENSP). E-mail: andrea.almeida@ensp.fiocruz.br, \\ rssantos@ensp.fiocruz.br \\ *Corresponding author
}

\begin{abstract}
This study sought to identify and spatialize the risk of transmission of Manson's schistosomiasis at localities in Pernambuco, Brazil that are used for tourist leisure activities and have freshwater environments that are inhabited by the snail that transmits this disease. In order to accomplish this, malacological surveys were conducted at the selected localities between May and December 2016, in order to identify and georeference the breeding sites and foci of schistosomiasis-transmitting mollusks of the genus Biomphalaria. The essential abiotic data for mollusk survival were evaluated at each breeding site: temperature, water $\mathrm{pH}$ and total dissolved solids (TDS). Data relating to breeding site quality were also recorded. The SPSS 20 software was used to analyze these data, and the chi-square test was applied to investigate associations between variables, taking a $p$-value $\leq 0.5$. Based on geographic coordinates, maps representing the distribution of breeding sites and foci, mollusk species found and numbers of mollusks sampled in each water body were created. ArcGIS 10.4 software was used to build thematic maps using the interpolation technique of inverse distance weighting (IDW). A total of 72 localities distributed among 44 municipalities located in the Metropolitan, Zona da Mata and Agreste regions of Pernambuco were investigated. At these, 26 reservoirs, 32 breeding sites and 10 foci of schistosomiasis intermediate hosts were found. The study identified and located problematic localities that are visited by special groups that through exposure to unhealthy environments are subject to infection by the parasite $S$. mansoni.
\end{abstract}

Keywords: environment, GIS, monitoring, schistosomiasis.

\section{Ambientes turísticos insalubres e transmissão da esquistossomose em Pernambuco, Brasil}

\section{RESUMO}


O presente estudo teve como objetivo identificar e espacializar o risco para transmissão da esquistossomose mansoni em localidades pernambucanas com ambientes aquáticos dulciaquícolas para a prática do turismo de lazer, onde existe a presença do caramujo transmissor da esquistossomose mansoni. Para isso foram realizados inquéritos malacológicos entre maio a dezembro de 2016 para identificar e georreferenciar os criadouros/focos de moluscos do gênero Biomphalaria, transmissores da esquistossomose. Em cada criadouro foram aferidos os dados abióticos essenciais para a sobrevivência dos moluscos: temperatura, pH da água e sólidos totais dissolvidos (TDS). Foram também registrados os dados relativos à qualidade do criadouro. Para análise desses dados foi utilizado o programa SPSS 20, e foi aplicado o teste qui-quadrado para verificar a associação entre as variáveis, considerando p-valor $\leq 0,5$. Com base nas coordenadas geográficas foram criados mapas da distribuição dos criadouros e focos, das espécies de moluscos encontrados e do número de moluscos coletados em cada coleção hídrica. Foi utilizado o programa ArcGIS 10.4. para construção de mapas temáticos usando a técnica de interpolação do Inverso da potência das distâncias (IDW). Foram investigadas 72 localidades distribuídas em 44 municípios localizados na Região Metropolitana, Zona da Mata e Agreste Pernambucano e nelas foram encontrados 26 reservatórios, 32 criadouros dos moluscos vetores e 10 focos de transmissão da esquistossomose. O presente estudo identificou e localizou com precisão localidades problemáticas e frequentadas por grupos especiais que, mediante exposição a ambientes insalubres, estão sujeitos à infecção pelo parasita Schistosoma mansoni.

Palavras-chave: esquistossomose, GIS, meio ambiente, monitoramento.

\section{INTRODUCTION}

Ecological tourism attracts nature lovers who choose leisure activities related to nature that offer accommodations and additional services. The Travelers' Health Guidelines studied people's movements and their interactions with various environments, in order to identify the risks to which tourists are exposed so that the tourists' health may be protected during their travels. Pre-trip vaccination is among the recommendations for tourists who come to Brazil. There are websites that provide information about preventive actions that aim to protect travelers and reduce the risk of epidemics (Brasil, 2005). However, movement of people is not an activity that is limited to tourism: it also includes migrant or refugee groups. Moreover, it must be borne in mind that, for some diseases, there is still no specific vaccination.

Locally, weekend recreational activities and second-home refuges need to be taken into account. The populations involved in such activities live close to natural tourist resources and are more exposed to unhealthy environments than are travelers who are just passing through. The Travelers' Health Guidelines need to acknowledge this diversity and healthcare services need to expand their differentiated action strategies in order to meet this challenge (Matos e Barcellos, 2010).

The state of Pernambuco presents a mild climate throughout the year and has a large network of natural water accumulations consisting of rivers and waterfalls that are attractive for water-related leisure activities. In this context, rural and coastal accommodation structures, inns, fish-and-pay establishments, resorts and travel agencies offer countless options for freshwater sports or leisure activities. Farm owners and urban entrepreneurs have been encouraged to diversify their activities through investing in structures for this type of recreation without proper attention to basic sanitation infrastructure that would provide health safety for freshwater leisure activities. Growth of the tourism industry contributes to the economic and social development of the state by attracting visitors. However, landscapes with natural water 
resources are becoming modified, and this is leading to serious damage to the environment (Agência Nacional de Águas, 2005).

Manson's schistosomiasis is a waterborne disease for which the etiological agent is the parasite Schistosoma mansoni. Its intermediate hosts are freshwater snails belonging to the genus Biomphalaria When parasitized individuals dispose of their feces, which includes the parasite's eggs, in water collection systems inhabited by these snails, these animals become infected with the Schistosoma miracidium and start transmitting the disease to other people who come into contact with these polluted waters.

In Pernambuco, schistosomiasis started as an endemic disease in the rural area of the Zona da Mata region, and now the foci are spread throughout the coast. It causes high rates of human infection, maintenance of acute and severe clinical forms and a significant number of deaths (Barbosa et al., 2016). A recent survey indicated 119 localities in Pernambuco where over 15\% of the population is parasitized and $97.5 \%$ of houses do not have sewage collection or treatment. This exposes 152,865 people to the risk of infection by S. mansoni (Saucha et al., 2015).

Poor sanitation conditions at localities that are endemic for schistosomiasis contribute to the spread of cases, with severe illness and deaths due to this disease. The relationship between the environment and lack of basic sanitation determines occurrences of waterborne diseases. Social groups that live in areas that lack sanitation services are subject to potentially greater adverse effects to their own health if they pollute freshwater accumulations where disease vectors proliferate.

Sewage discharge into rivers, ponds and peridomestic ditches creates unhealthy environments that favor transmission of parasitic diseases. Examples of this include the severe schistosomiasis outbreaks that occurred in the metropolitan areas of Belo Horizonte, Minas Gerais, Recife, Pernambuco (Barbosa et al., 2011) and Aracaju, Sergipe (de Jesus et al., 2002), and in the interior of the state of São Paulo. Recently, in the Chapada Diamantina region (Bahia), 32 tourists became infected after swimming in a local pond. Thus, in resorts and parks, travelers become susceptible to this parasitic disease when exposed to water contaminated with fecal material.

The term "environmental risk" refers to situations that present a risk relating to what surrounds the individual, which may be the natural environment (natural risk) or a man-made environment (social and technological risk) resulting from human actions and occupation of territory (Dagnino e Carpi, 2007).

Travelers who are exposed to this environmental risk and who become infected by $S$. mansoni develop the acute form of the disease, if there has been no previous contact between the individual and this parasite. However, the acute infection is self-limited and so these travelers may return home without presenting typical signs of infection. Timely treatment of the disease is thus delayed, which contributes towards its spread into disease-free areas, given that travelers move between endemic and non-endemic areas (Barreto et al., 2016).

This study sought to identify and spatialize the risk of transmission of Manson's schistosomiasis at localities in Pernambuco that are inhabited by the snail that transmits this disease and that have freshwater environments used for tourism.

\section{MATERIAL AND METHODS}

Localities in municipalities in the Agreste and Zona da Mata regions and in the Metropolitan Region of Recife were selected using the Rural Tourism Guidelines of Pernambuco and accommodation websites for this state.

Malacological surveys were conducted at these selected localities between May and December 2016 and were made with appropriate tools, like forceps, according to the depth of the water collection, following the method developed by Olivier and Schneiderman (1956), in 
order to identify and georeference (using the Garmin eTrex ${ }^{\circledR} 20$ GPS) breeding sites (reservoirs with intermediate host snails) of Biomphalaria and foci (breeding sites with infected mollusks) of schistosomiasis transmission. Intermediate hosts were sampled and sent to the Schistosomiasis Laboratory and Reference Service of Aggeu Magalhães Institute - Fiocruz, in order to identify the species and detect infectivity due to $S$. mansoni, using the traditional light exposure technique (Kuntz, 1946) and the polymerase chain reaction (PCR), which is sensitive and specific for diagnosing low loads of parasitic infection (Melo et al., 2006).

The essential abiotic data for mollusk survival were evaluated at each breeding site: temperature, water $\mathrm{pH}$ and total dissolved solids (TDS) were measured in loco with a digital spit thermometer, digital $\mathrm{pH}$ meter and digital TDS meter, respectively. Data relating to breeding site quality were also recorded: natural or artificial water accumulation, presence of sewage, presence of vegetation cover, water transparency and the sediment composition. Breeding sites were classified as natural (pond, river or waterfall) or artificial (natural pools or fish-and-pay ponds). The SPSS 20 software was used to analyze these data, and the chi-square test was applied to investigate associations between variables, taking the $p$-value $\leq 0.5$.

Based on geographic coordinates, maps representing the distribution of breeding sites and foci of transmission, mollusk species found and numbers of mollusks sampled in each water accumulation were created. The ArcGIS 10.4 software was used to build thematic maps using the interpolation technique of inverse distance weighting (IDW). The IDW interpolator determines values for unknown areas by calculating the weighted mean using the inverse of the distance between this area and a point where the value is known (Harman et al., 2016). The Equation 1 to determine the values of interpolation areas is described by the following formula:

$N_{0}=\frac{\sum_{i}^{n}=1 N i \cdot P i}{\sum_{i}^{n}=1 \quad P i}$

Where:

$n$ represents the number of known points;

$N i$ is the interpolation value at position $i$

and $P i$ is the weight of each interpolation value at position $i$.

\section{RESULTS AND DISCUSSION}

A total of 72 localities distributed among 44 municipalities located in the Metropolitan, Zona da Mata and Agreste regions of Pernambuco were investigated. At these, 26 reservoirs, 32 breeding sites of intermediate hosts and 10 foci of schistosomiasis transmission were found. The correlation analysis (Pearson and Spearman coefficients) and chi-square and Fisher tests did not show any statistically significant differences in presence of schistosomiasis intermediate hosts in relation to the variables of each breeding site environment (Table 1).

Figure 1 shows the geographic distribution of breeding sites and species of schistosomiasis intermediate hosts at leisure localities. At 36 breeding sites, the species was Biomphalaria straminea and at 6 sites it was B. glabrata. The breeding sites for B. straminea at which presence of S. mansoni DNA was diagnosed by means of PCR were considered to be potential foci (6 breeding sites were positive). At 4 breeding sites where B. glabrata was found, snails were found to be releasing infecting cercariae. Therefore, these can be considered to be active transmission foci for schistosomiasis. 
Table 1. Abiotic data, quality of breeding sites of intermediate hosts and foci of schistosomiasis transmission sampled from municipalities in Pernambuco.

\begin{tabular}{|c|c|c|c|c|c|c|}
\hline & \multicolumn{2}{|c|}{ reservoirs } & \multicolumn{2}{|c|}{ breeding sites or foci } & \multicolumn{2}{|c|}{ Total } \\
\hline & $\mathrm{N}$ & $\%$ & $\mathrm{~N}$ & $\%$ & $\mathrm{~N}$ & $\%$ \\
\hline \multicolumn{7}{|l|}{ Temperature range $\left({ }^{\circ} \mathbf{C}\right)$} \\
\hline De 22 a 26 & 17 & 65.4 & 21 & 60 & 38 & 62.3 \\
\hline De 27 a 32 & 9 & 34.6 & 14 & 40 & 23 & 37.7 \\
\hline \multicolumn{7}{|l|}{ pH range } \\
\hline De 6,1 a 9 & 23 & 88.5 & 25 & 71.4 & 48 & 78.7 \\
\hline De 9,1 a 10,8 & 3 & 11.5 & 10 & 28.6 & 13 & 21.3 \\
\hline \multicolumn{7}{|l|}{ TDS range } \\
\hline De 0 a 500 & 22 & 84.6 & 33 & 94.3 & 55 & 90.2 \\
\hline De 501 a 950 & 4 & 15.4 & 2 & 5.7 & 6 & 9.8 \\
\hline \multicolumn{7}{|l|}{ Breeding site type } \\
\hline Artificial & 7 & 26.9 & 7 & 20 & 14 & 23 \\
\hline Natural & 19 & 73.1 & 28 & 80 & 47 & 77 \\
\hline \multicolumn{7}{|l|}{ The environment } \\
\hline natural & 24 & 92.3 & 28 & 80 & 52 & 85.2 \\
\hline modified & 2 & 7.7 & 7 & 20 & 9 & 14.8 \\
\hline \multicolumn{7}{|l|}{ Sewage or trash } \\
\hline absent & 26 & 100 & 30 & 85.7 & 56 & 91.8 \\
\hline presence & 0 & 0 & 5 & 14.3 & 5 & 8.2 \\
\hline \multicolumn{7}{|l|}{ Natural vegetation } \\
\hline absent & 2 & 7.7 & 2 & 5.7 & 4 & 6.6 \\
\hline presence & 24 & 92.3 & 33 & 94.3 & 57 & 93.4 \\
\hline \multicolumn{7}{|l|}{ Water transparency } \\
\hline clear & 17 & 65.4 & 18 & 51.4 & 35 & 57.4 \\
\hline turbid & 9 & 34.6 & 17 & 48.6 & 26 & 42.6 \\
\hline \multicolumn{7}{|l|}{ Sediment type } \\
\hline mud or sand & 16 & 61.5 & 23 & 65.7 & 39 & 63.9 \\
\hline others (stone or cement) & 10 & 38.5 & 12 & 34.3 & 22 & 36.1 \\
\hline
\end{tabular}




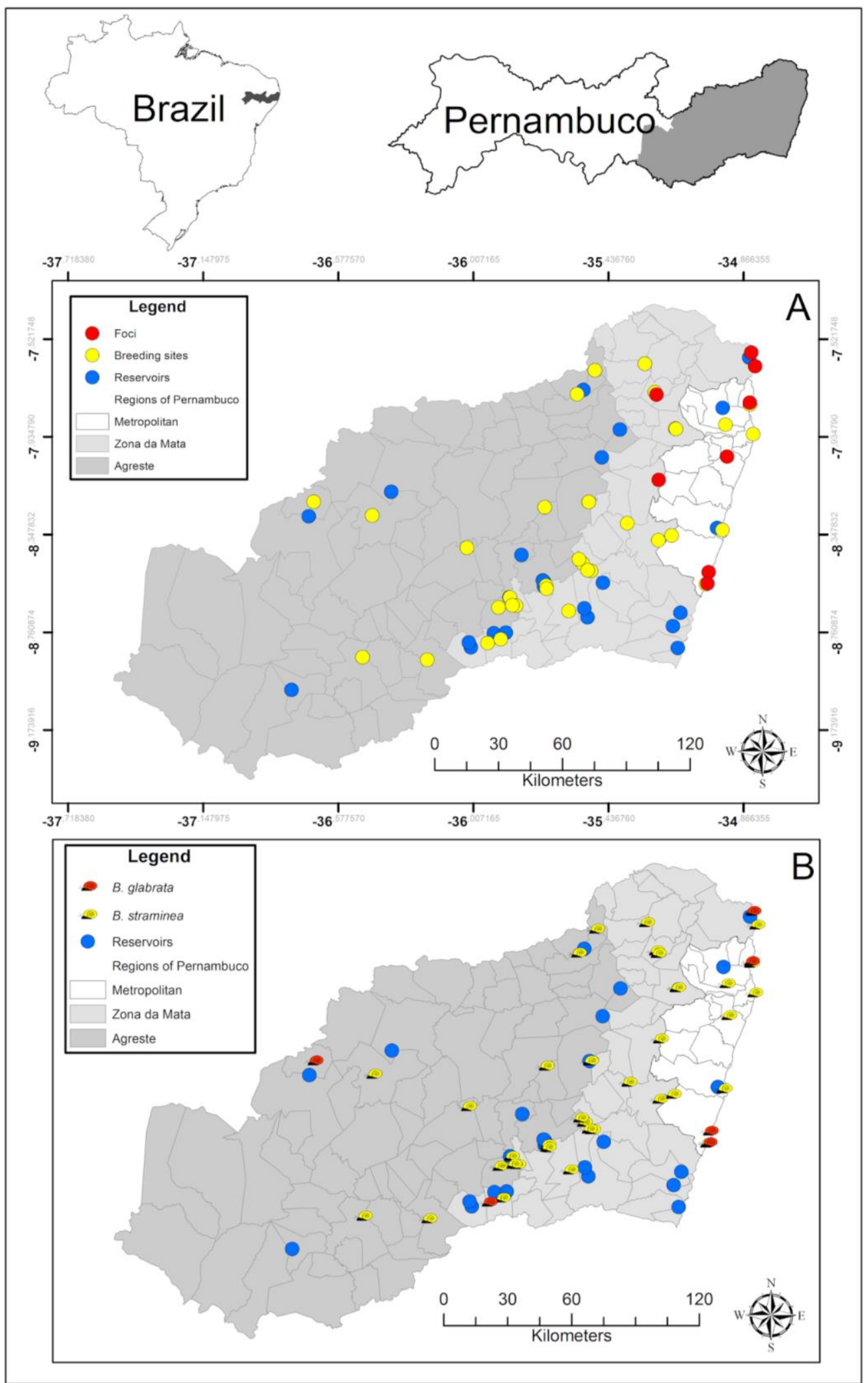

Figure 1. A. Locations of reservoirs, breeding sites of intermediate hosts and foci of schistosomiasis transmission identified at touristic or water-activity leisure localities in Pernambuco; B. Species of intermediate hosts found at breeding sites. 
Figure 2 shows the numbers of snails sampled from each breeding site. Two breeding sites located at touristic localities on the coast of Pernambuco (Porto de Galinhas and Serrambi) where large numbers of the snail B. glabrata infected by $S$. mansoni were collected are highlighted.

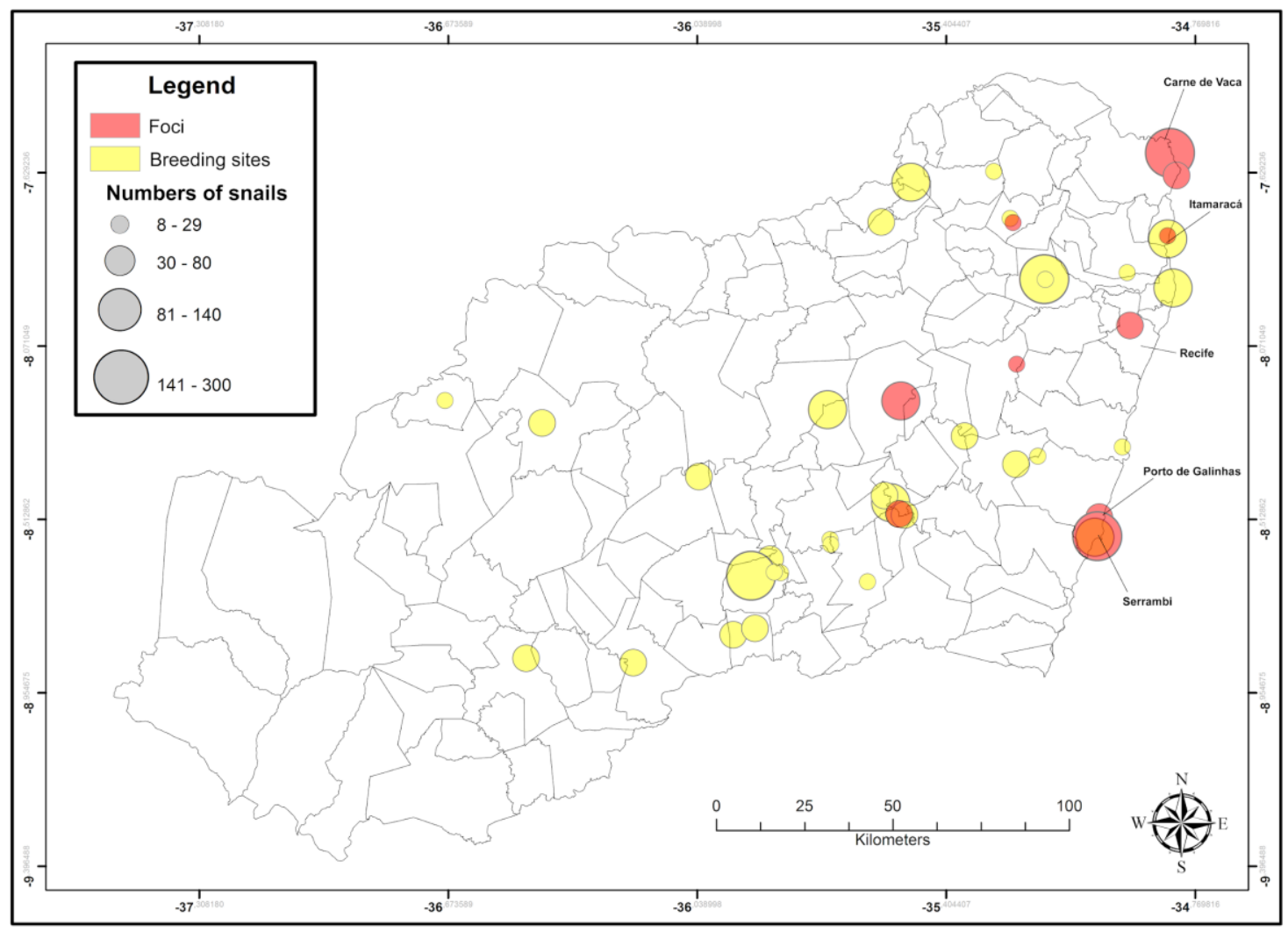

Figure 2. Numbers of specimens sampled from breeding sites of intermediate hosts and foci of schistosomiasis transmission identified at water-activity leisure localities in Pernambuco.

Figure 3 shows that the results regarding the physical-chemical conditions of the water accumulations were very similar, both for breeding sites and for reservoirs, thus indicating that these reservoirs were susceptible to colonization by schistosomiasis intermediate hosts.

The data that resulted from the present study made it possible to construct thematic maps that indicated schistosomiasis transmission risk areas in touristic water-activity leisure localities in Pernambuco that are breeding sites for schistosomiasis-transmitting snails. These breeding sites become transmission foci for the disease in the absence of local sanitation systems, which leads to fecal pollution of freshwater bodies and favors waterborne diseases, thus threatening the health of tourist populations engaged in aquatic recreational activities in Pernambuco.

The fact that no association regarding specific ecological conditions that favored or differentiated breeding sites from reservoirs was found indicated that the aquatic environments studied presented the same favorable characteristics and conditions for the intermediate hosts' survival, and that they were able to quickly transform into breeding sites and/or foci. Spatial analysis using the IDW estimator was an important epidemiological tool, complementary to the statistical analysis of this study. It showed, in map form, that reservoirs, breeding sites of intermediate hosts and foci of schistosomiasis transmission, are found under similar physicalchemical conditions. This facilitates intermediate host colonization and enables the spread of disease. The spatial distribution and numbers of mollusks sampled showed the spot intensity of the disease and the occurrence of each event. This makes it possible to undertake situational analyses in the future, in order to predict the epidemiological and spatial dimensions of the disease in the study area. 


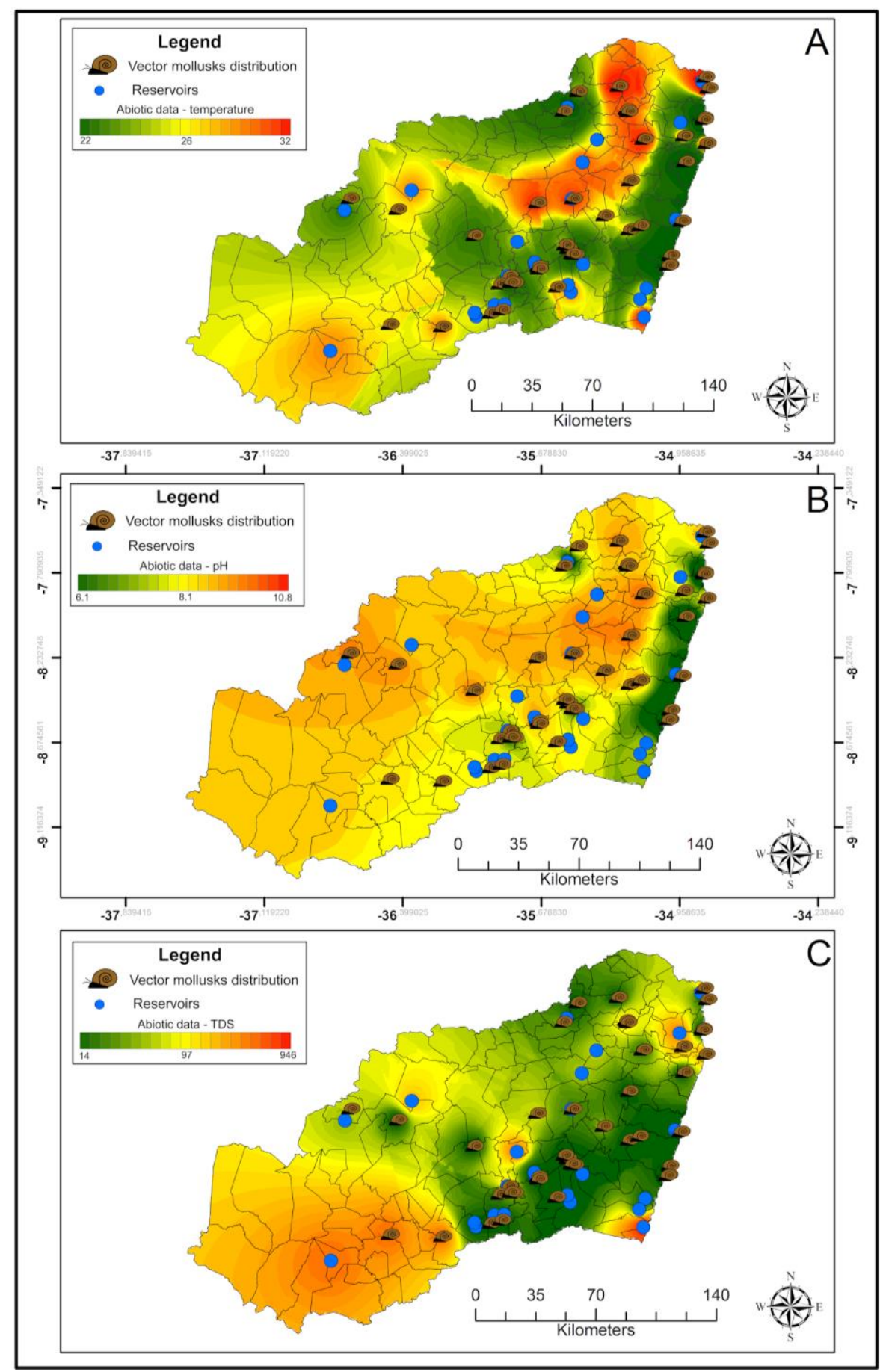

Figure 3. IDW interpolator of temperature (A), $\mathrm{pH}(\mathrm{B})$ and TDS (C) data from breeding sites of intermediate hosts and foci of schistosomiasis transmission, and from reservoirs which were identified at water-activity leisure localities in Pernambuco.

Among the 8 foci identified, the epidemiological importance of the four foci of the intermediate host $B$. glabrata at which cercariae of $S$. mansoni were being eliminated needs to be highlighted. These represent situations of active transmission of the disease at coastal localities such as Itamaracá, Serrambi, Porto de Galinhas and Carne de Vaca, which are important resorts in Pernambuco, visited by tourists and local vacationers throughout the year. In these coastal areas, there are no natural water accumulations and transmission of schistosomiasis is seasonal, governed by the rainy season (May to August). During this period, 
peripheral foci overflow and infected snails are carried into the streets. These artificial and peridomestic foci are formed by wastewater that is discharged into the environment, in communities that dwell in areas surrounding the resorts (Barbosa et al., 2015a; 2015b).

When tourists disembark in Recife, they receive an information leaflet on "Rural Routes in Pernambuco", which indicates localities with freshwater leisure attractions that are located in areas that are endemic for schistosomiasis. Considering that these localities receive visitors throughout the year, information needs to be provided for them regarding the risks that they may be exposed to when visiting water bodies at localities with foci of schistosomiasis transmission, and the risk that they run of becoming agents that disseminate parasitic diseases into nonendemic areas. Travelers' health precautions should be based on a set of actions and partnerships between governments, travel agencies and health surveillance sectors, in order to provide proper and precise information about the risks present in aquatic leisure environments, with the aim of protecting people who visit these areas.

Some of the problems relating to ecotourism are far from being resolved, such as insistence that tourism entrepreneurs should follow the technical norms issued by the Brazilian Association of Ecotourism and Adventure Tourism Agencies (ABETA) and sanctions for those that do not conform. This Association has been active throughout Brazil since 2004 and is responsible for management and implementation of the Safe Adventure Program, in partnership with the National Serviço Brasileiro de Apoio às Micro e Pequenas Empresas (SEBRAE), the Ministry for Tourism, and the main Brazilian ecotourism and adventure tourism agencies (Abeta e Ministério do Turismo, 2009).

\section{CONCLUSIONS}

Although the present study was only descriptive, it precisely identified and located problematic localities that are visited by tourist groups that, through exposure to unhealthy environments, are subject to infection by the parasite S. mansoni. Expansion of this knowledge is necessary in order to evaluate the environmental characteristics responsible for maintenance of these foci of the disease transmission, and thus to produce more significant conclusions that might become effective public healthcare strategies that minimize the impact of transmission of this disease among local populations and tourists who come to this state seeking leisure in its beautiful landscapes.

\section{ACKNOWLEDGEMENTS}

The field technicians and microscopists of the IAM/Fiocruz Schistosomiasis Laboratory for their support in all phases of this work.

The National Council for Scientific and Technological Development (CNPq) for promoting this study $-\mathrm{n}^{\circ}$ 470305/2014-2.

\section{REFERENCES}

ABETA; BRASIL. Ministério do Turismo. Manual de boas práticas: aventura segura: sistema de gestão da segurança. Belo Horizonte: Ministério do Turismo, 2009. v. 2

AGÊNCIA NACIONAL DE ÁGUAS - ANA (Brasil). Cadernos de recursos hídricos: o turismo e o lazer e sua interface com o setor de recursos hídricos. Brasília, 2005.

BARBOSA, C. S. et al. The endemisation of schistosomiasis in Porto de Galinhas, Pernambuco, Brazil, 10 years after the first epidemic outbreak. Memórias do Instituto Oswaldo Cruz, v. 106, n. 7, p. 878-83, 2011. http://dx.doi.org/10.1590/S0074-02762011000700014 
BARBOSA, C. S. et al. Turismo de risco para esquistossomose mansônica em Porto de Galinhas, Estado de Pernambuco, Brasil. Revista Pan-Amazônica de Saúde, v. 6, n. 3, p. 51-58, 2015a. http://dx.doi.org/10.5123/S2176-62232015000300007

BARBOSA, C. S. et al. Epidemiologia da esquistossomose no litoral de Pernambuco. Revista de Patologia Tropical, v. 43, n. 4, p. 436-445, $2015 \mathrm{~b}$. https://doi.org/10.5216/rpt.v43i4.33607

BARBOSA, C. S. et al. Morbidity of mansoni schistosomiasis in Pernambuco-Brazil: Analysis on the temporal evolution of deaths, hospital admissions and severe clinical forms (19992014). Acta Tropica, v. 164, p. 10-16, 2016. https://doi.org/10.1016/j.actatropica.2016.06.024

BARRETO, M. S.; DE SOUZA GOMES, E. C.; BARBOSA, C. S. Turismo de risco em áreas vulneráveis para a transmissão da esquistossomose mansônica no Brasil. Cadernos de Saude Publica, v. 32, n. 3, p. 1-3, 2016. https://doi.org/10.1590/0102-311X00190815

BRASIL. Ministério da Saúde. Guia de vigilância epidemiológica. 6. ed. Brasília, 2005.

DAGNINO, R. D. S.; CARPI, S. Risco ambiental: conceitos e aplicações. Climatologia e Estudos da Paisagem, v. 2, n. 2, p. 50-87, 2007.

DE JESUS, A. R. et al. Clinical and Immunologic evaluation of 31 patients with Acute Schistosomiasis mansoni. The Journal of Infectious Diseases, v. 185, n. 1, p. 98-105, 2002. https://doi.org/10.1086/324668

HARMAN, B. I.; KOSEOGLU, H.; YIGIT, C. O. Performance evaluation of IDW, Kriging and multiquadric interpolation methods in producing noise mapping: A case study at the city of Isparta, Turkey. Applied Acoustics, v. 112, p. 147-157, 2016. https://doi.org/10.1016/j.apacoust.2016.05.024

KUNTZ, R. Effect of light and temperature on shedding of Schistosoma mansom cercariae. Effect of light and temperature on shedding of, v. 7, p. 16, 1946.

MATOS, V.; BARCELLOS, C. Relações entre turismo e saúde: abordagens metodológicas e propostas de ação. Revista Panamericana de Salud Pública, v. 28, n. 2, p. 128-134, 2010.

MELO, F. L. et al. Development of molecular approaches for the identification of transmission sites of schistosomiasis. Transactions of the Royal Society of Tropical Medicine and Hygiene, v. 100, n. 11, p. 1049-1055, 2006. https://doi.org/10.1016/j.trstmh.2005.12.008

OLIVIER, L.; SCHNEIDERMAN, M. A method for estimating the density of aquatic snail populations. Experimental Parasitology, v. 5, n. 2, p. 109-117, 1956. http://dx.doi.org/10.1016/0014-4894(56)90008-X

SAUCHA, C. V. V.; SILVA, J. A. M. DA; AMORIM, L. B. Condições de saneamento básico em áreas hiperendêmicas para esquistossomose no estado de Pernambuco em 2012. Epidemiologia e Serviços de Saúde, v. 24, n. 3, p. 497-506, 2015. https://doi.org/10.5123/S1679-49742015000300015 